\title{
On the Mechanism of Serotonin-Induced Dipsogenesis in the Rat $^{1}$
}

\author{
DIANNE C. KIKTA, ${ }^{2}$ CHRISTOPHER C. BARNEY, ${ }^{3}$ \\ ROSE M. THREATTE, ${ }^{4}$ MELVIN J. FREGLY, ${ }^{5}$ \\ NEIL E. ROWLAND AND JOHN E. GREENLEAF 6 \\ Department of Physiology, University of Florida, College of Medicine \\ and Department of Psychology, College of Liberal Arts and Sciences, Gainesville, FL 32610
}

Received 3 February 1983

\begin{abstract}
KIKTA, D. C., C. C. BARNEY, R. M. THREATTE, M. J. FREGLY, N. E. ROWLAND AND J. E. GREENLEAF. On the mechanism of serotonin-induced dipsogenesis in the rat. PHARMACOL BIOCHEM BEHAV 19(3) 519-525, 1983.Subcutaneous administration of $l-5$-hydroxytryptophan (5-HTP), the precursor of serotonin, to female rats induces copious drinking accompanied by activation of the renin-angiotensin system. Neither a reduction in blood pressure nor body temperature accompanied administration of 5-HTP. The objective of the present study was to determine whether serotonin-induced dipsogenesis, like that of 5-HTP, is mediated via the renin-angiotensin system. Serotonin $(2 \mathrm{mg} / \mathrm{kg}$, $\mathrm{SC}$-induced drinking was inhibited by the dopaminergic antagonist, haloperidol $(150 \mu \mathrm{g} / \mathrm{kg}$, IP), which also inhibits angiotensin II-induced drinking. Both captopril $(35 \mathrm{mg} / \mathrm{kg}$. IP), an angiotensin converting enzyme inhibitor, and propranolol $\left(6 \mathrm{mg} / \mathrm{kg}\right.$, IP), a $\beta$-adrenergic antagonist, blocked serotonin-induced dipsogenesis. The $\alpha_{2}$-adrenergic agonist, clonidine $(6.25 \mu \mathrm{g} / \mathrm{kg}, \mathrm{SC})$, which suppresses renin release from the kidney, attenuated serotonin-induced water intake. The dipsogenic responses to submaximal concentrations of both serotonin $(1 \mathrm{mg} / \mathrm{kg}, \mathrm{SC})$ and isoproterenol $(8 \mu \mathrm{g} / \mathrm{kg} . \mathrm{SC}) \mathrm{were}$ additive rather than interactive suggesting that similar pathways mediate both responses. The serotonergic receptor antagonist, methysergide $(3 \mathrm{mg} / \mathrm{kg}$. IP), inhibited serotonin-induced drinking but had no effect on isoproterenol $(25 \mu \mathrm{g} / \mathrm{kg}$, $\mathrm{SC}$ )-induced dipsogenesis. However, neither serotonin $(2 \mathrm{mg} / \mathrm{kg}, \mathrm{SC})$ nor isoproterenol $(25 \mu \mathrm{g} / \mathrm{kg}, \mathrm{SC})$-induced drinking was inhibited by cinanserin $(25 \mu \mathrm{g} / \mathrm{kg}$, IP). These data indicate that serotonin induces drinking in rats via the renin-angiotensin system. However, the results of the studies using methysergide suggest that serotonin appears to act at a point prior to activation of $\beta$-adrenoceptors in the pathway leading to release of renin from the kidneys.
\end{abstract}

Serotonin Water intake Renin-angiotensin system Captopril Propranolol Clonidine Isoproterenol Methysergide Cinanserin

PREVIOUS studies from this laboratory have shown that 5-hydroxytryptophan (5-HTP), the immediate precursor of serotonin, is a potent dipsogen when administered peripherally to rats $[12,18,29]$. The dipsogenic response to 5 -HTP is inhibited by the peripheral decarboxylase inhibitor, carbidopa; by the dopaminergic antagonists, haloperidol and spiperone; by the $\beta$-adrenergic antagonist, propranolol, by the angiotensin I converting enzyme inhibitor, captopril, and by a peripheral serotonin receptor antagonist, methysergide $[18,29]$. The dipsogenic effect of 5-HTP is accompanied by an increase in plasma renin activity, but no significant change in either blood pressure or body temperature [3]. Attenuation of the dipsogenic response to 5-HTP by a peripheral decarboxylase inhibitor and a serotonin receptor antagonist suggests that it must be converted to serotonin peripherally to induce drinking. The results further suggest that the newly formed serotonin activates the renin- angiotensin system since the dipsogenic response to 5-HTP could be inhibited by propranolol and captopril and an increase in plasma renin activity accompanied its administration. Serotonin is known both to stimulate drinking and to increase plasma renin activity in rats $[3,21,22]$ but the latter has been attributed to a reduction in blood pressure which also accompanies its administration. A fundamental difference between the responses to peripheral administration of 5-HTP and serotonin to rats is that blood pressure failed to change in the case of the former and decreased in the case of the latter [3].

The objective of the present study was to assess more thoroughly the dependence of the dipsogenic response to serotonin on the renin-angiotensin system. To this end, the effects of the dopaminergic receptor antagonist, haloperidol; the renin-angiotensin system antagonists, propranolol, captopril, and clonidine; and the serotonin receptor antagonist,

\footnotetext{
'Supported by contract NCA2-OR240-101 from the National Aeronautics and Space Administration, Moffett Field, CA.

${ }^{2}$ Research Fellow of the American Heart Association. Suncoast Chapter, Inc.

${ }^{3}$ Present address: Department of Biology. Peale Science Center, Hope College, Holland. MI.

'Present address: Monell Chemical Senses Center, 3500 Market Street, Philadelphia. PA.

${ }^{5}$ Requests for reprints should be addressed to Dr. Melvin J. Fregly, Department of Physiology, Box J-274, JHMHC, College of Medicine, Gainesville, FL 32610.

${ }^{6}$ Present address: Biomedical Research Division, NASA-Ames Research Center, Moffett Field, CA.
} 
cinanserin, on serotonin-induced thirst were studied in rats. In addition, both the interaction between serotonin and isoproterenol, a $\beta$-adrenoceptor agonist, on drinking and the effect of methysergide and cinanserin on the dipsogenic response to isoproterenol were studied. The results indicate that serotonin, like 5-HTP, induces drinking in rats via the renin-angiotensin system. However, serotonin appears to act at some step prior to activation of the $\beta$-adrenoceptors in the kidneys.

\section{METHOD}

A total of sixty-eight female rats of the Blue Spruce Farms (Hooded) strain were used for all the experiments described here. Forty of the rats weighing 230 to $330 \mathrm{~g}$, were used for the first 4 experiments. The remaining rats, weighing 270 to $320 \mathrm{~g}$, were used for Experiments 5,6 and 7 . The rats were housed 4 per cage in a room maintained at $24 \pm 1^{\circ} \mathrm{C}$ and illuminated from $7 \mathrm{a} . \mathrm{m}$. to $7 \mathrm{p} . \mathrm{m}$. All rats were provided with Purina Laboratory Chow and tap water ad lib prior to all experiments.

For each experiment, 24 of the rats were divided randomly into 4 groups of 6 each. At least 7 days were allowed between experiments. One hr prior to the beginning of an experiment, the 24 rats were weighed and placed in individual stainless steel metabolism cages equipped with water bottles which consisted of infant nursing bottles with cast bronze spouts as described by Lazarow [19]. The temperature of the water was $24^{\circ} \mathrm{C}$. Food was not available during the experiments. All experiments were begun between 9 and 10 a.m. All compounds tested were dissolved in saline (except captopril, which was dissolved in double-distilled water) to give $1 \mathrm{ml} / \mathrm{kg}$ of body weight. Concentrations of compounds tested are not expressed as the base compound.

Although water intake has been reported to be influenced by the phase of the estrus cycle of female rats [8], a recent study from this laboratory has shown that this effect can be masked by a moderate dose of isoproterenol [13]. Hence, the use of female rats in tests of water intake is justified under these conditions and when randomization of both treatment and animals is carried out, as it was in the present studies.

\section{Experiment I: Effect of Haloperidol on Serotonin-Induced Water Intake}

The $\mathbf{4}$ groups of rats used for this experiment were treated as follows: Group 1 (control) received isotonic saline (1 $\mathrm{ml} / \mathrm{kg}$. IP) followed by isotonic saline $(1 \mathrm{ml} / \mathrm{kg}, \mathrm{SC}) 1 \mathrm{hr}$ later. Group 2 received haloperidol ( $150 \mu \mathrm{g} / \mathrm{kg}$, IP) followed by isotonic saline $\mathrm{SC} 1 \mathrm{hr}$ later. Group 3 received isotonic saline IP followed by serotonin $(2 \mathrm{mg} / \mathrm{kg}, \mathrm{SC}) 1 \mathrm{hr}$ later. Group 4 received haloperidol $(150 \mu \mathrm{g} / \mathrm{kg}$, IP) followed by serotonin $(2 \mathrm{mg} / \mathrm{kg}, \mathrm{SC}) 1 \mathrm{hr}$ later. The water bottles were weighed prior to the second administration of drug and returned to the metabolism cages immediately following the second injection.

\section{Experiment 2: Effect of Captopril on Serotonin-Induced Water Intake}

The 4 groups of rats used for this experiment were treated as follows: Group 1 (control) received double-distilled water $(1 \mathrm{ml} / \mathrm{kg}, \mathrm{IP})$ followed by isotonic saline $(1 \mathrm{ml} / \mathrm{kg}$. SC) $15 \mathrm{~min}$ later. Group 2 received captopril $(35 \mathrm{mg} / \mathrm{kg}$. IP) followed by isotonic saline $15 \mathrm{~min}$ later. Group 3 received doubledistilled water followed by serotonin $(2 \mathrm{mg} / \mathrm{kg}$. SC) $15 \mathrm{~min}$ later. Group 4 received captopril ( $35 \mathrm{mg} / \mathrm{kg}$, IP) followed by serotonin $(2 \mathrm{mg} / \mathrm{kg}$, SC) $15 \mathrm{~min}$ later. Water intake was measured as described for Experiment 1.

\section{Experiment 3: Effect of Propranolol on Serotonin-Induced Water Intake}

The 4 groups of rats used for this experiment were treated as follows: Group 1 (control) received isotonic saline $(1 \mathrm{ml} / \mathrm{kg}$, IP) followed by isotonic saline $(1 \mathrm{ml} / \mathrm{kg}, \mathrm{SC}) 30 \mathrm{~min}$ later. Group 2 received propranolol $(6 \mathrm{mg} / \mathrm{kg}$, IP) followed by isotonic saline $(1 \mathrm{ml} / \mathrm{kg}, \mathrm{SC}) 30 \mathrm{~min}$ later. Group $3 \mathrm{received}$ isotonic saline (1 $\mathrm{ml} / \mathrm{kg}$, IP) followed by serotonin $(2 \mathrm{mg} / \mathrm{kg}$, SC) $30 \mathrm{~min}$ later. Group 4 received propranolol $(6 \mathrm{mg} / \mathrm{kg}$, IP) followed by serotonin $(2 \mathrm{mg} / \mathrm{kg}, \mathrm{SC}) 30 \mathrm{~min}$ later. Water intake was measured as described for Experiment 1.

\section{Experiment 4: Effect of Clonidine on Serotonin-Induced Water Intake}

The 4 groups of rats used for this experiment were treated as follows: Group 1 (control) received isotonic saline (1 $\mathrm{ml} / \mathrm{kg}, \mathrm{SC})$ followed by isotonic saline $(1 \mathrm{ml} / \mathrm{kg}, \mathrm{SC}) 15 \mathrm{~min}$ later. Group 2 received clonidine $(6.25 \mu \mathrm{g} / \mathrm{kg}, \mathrm{SC})$ followed by isotonic saline $15 \mathrm{~min}$ later. Group 3 received isotonic saline followed by serotonin $(2 \mathrm{mg} / \mathrm{kg}, \mathrm{SC}) 15 \mathrm{~min}$ later. Group 4 received clonidine $(6.25 \mu \mathrm{g} / \mathrm{kg}, \mathrm{SC})$ followed by serotonin $(2 \mathrm{mg} / \mathrm{kg}, \mathrm{SC}) 15 \mathrm{~min}$ later. Water intake was measured as described for Experiment 1.

\section{Experiment 5: Interaction Between Serotonin and Isoproterenol on Induction of Drinking}

The 4 groups of rats used for this experiment were treated as follows: Group 1 (control) received isotonic saline (I $\mathrm{ml} / \mathrm{kg}, \mathrm{SC})$ followed by isotonic saline $(1 \mathrm{ml} / \mathrm{kg}, \mathrm{SC}) 30 \mathrm{~min}$ later. Group 2 received serotonin ( $1 \mathrm{mg} / \mathrm{kg}, \mathrm{SC}$ ) followed by isotonic saline $30 \mathrm{~min}$ later. Group 3 received isotonic saline followed by isoproterenol $(8 \mu \mathrm{g} / \mathrm{kg}, \mathrm{SC}) 30 \mathrm{~min}$ later. Group 4 received serotonin $(1 \mathrm{mg} / \mathrm{kg}, \mathrm{SC}$ ) followed by isoproterenol $(8 \mu \mathrm{g} / \mathrm{kg}$. SC) $30 \mathrm{~min}$ later. Water intake was measured as described for Experiment 1, except the third hr measurement was omitted. Serotonin was administered $30 \mathrm{~min}$ prior to isoproterenol because the onset of drinking following serotonin [18] is slower than that for isoproterenol [4].

Experiment 6: Effect of Methysergide on IsoproterenolInduced Water Intake

The 4 groups of rats used in this experiment were treated as follows: Group 1 (control) received isotonic saline (1 $\mathrm{ml} / \mathrm{kg}$. IP) followed by isotonic saline $(1 \mathrm{ml} / \mathrm{kg}, \mathrm{SC}) 15 \mathrm{~min}$ later. Group 2 received methysergide ( $3 \mathrm{mg} / \mathrm{kg}$. IP) followed by isotonic saline $(1 \mathrm{ml} / \mathrm{kg}, \mathrm{SC}) 15 \mathrm{~min}$ later. Group $3 \mathrm{re}-$ ceived isotonic saline $(1 \mathrm{ml} / \mathrm{kg}$, IP) followed by isoproterenol $(25 \mu \mathrm{g} / \mathrm{kg}, \mathrm{SC}) 15 \mathrm{~min}$ later. Group 4 received methysergide ( $3 \mathrm{mg} / \mathrm{kg}$, IP) followed by isoproterenol $(25 \mu \mathrm{g} / \mathrm{kg}, \mathrm{SC}) 15 \mathrm{~min}$ later. Water intake was measured as described for Experiment 1 , except the third $\mathrm{hr}$ measurement was omitted.

Experiment 7: Effect of Cinanserin on Isoproterenot- and Serotonin-Induced Water Intake

In the first part of this experiment, the 4 groups were treated as follows: Group 1 (control) received isotonic saline $(1 \mathrm{ml} / \mathrm{kg}, \mathrm{SC})$ followed by isotonic saline $(1 \mathrm{ml} / \mathrm{kg}$, IP) $15 \mathrm{~min}$ later. Group 2 received cinanserin $(25 \mathrm{mg} / \mathrm{kg}$, IP) followed by isotonic saline $(1 \mathrm{ml} / \mathrm{kg}, \mathrm{SC}) 15 \mathrm{~min}$ later. Group 3 received 


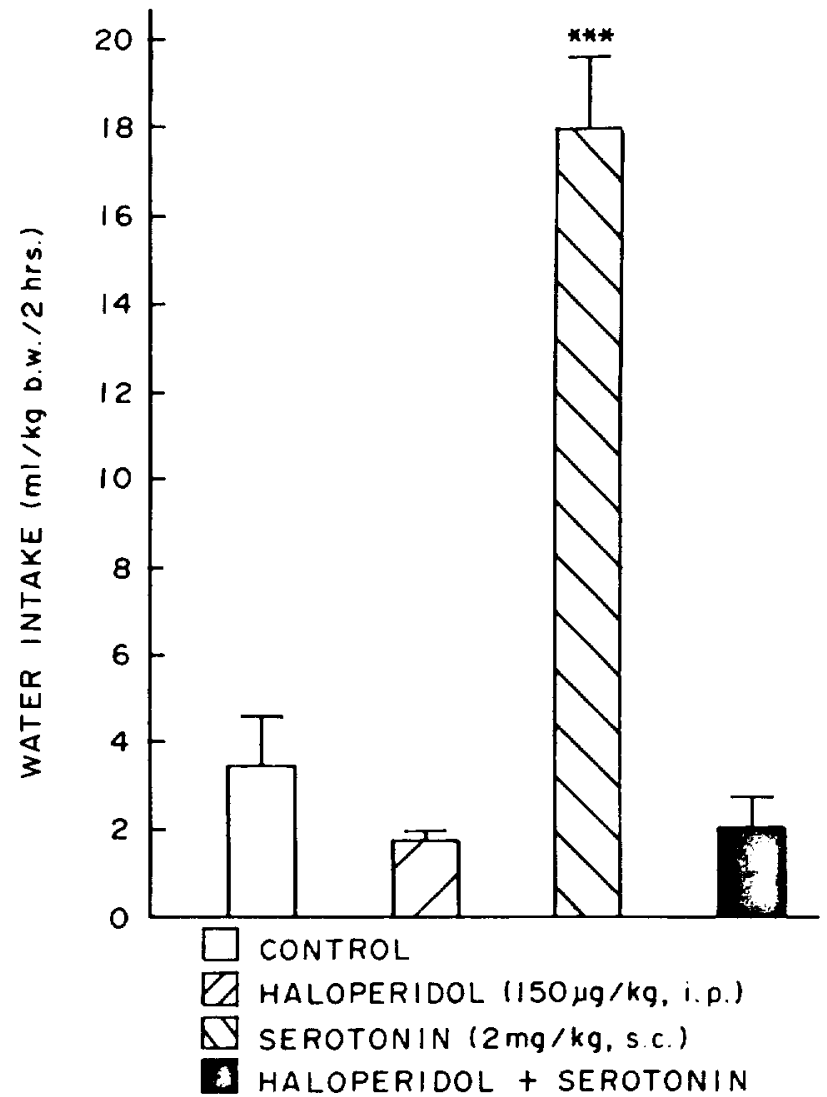

FIG. 1. Effect of pretreatment for $1 \mathrm{hr}$ with haloperidol $(150 \mu \mathrm{g} / \mathrm{kg}$. IP) on the dipsogenic response to serotonin $(2 \mathrm{mg} / \mathrm{kg}, \mathrm{SC})$. Cumulative water intake during the first $2 \mathrm{hr}$ after administration of the dipsogen is shown. Significant difference from control is denoted: ${ }^{* * *} p<0.001$.

isotonic saline ( $1 \mathrm{ml} / \mathrm{kg}$, IP) followed by isoproterenol (25 $\mu \mathrm{g} / \mathrm{kg}, \mathrm{SC}$ ) $15 \mathrm{~min}$ later. Group 4 received cinanserin (25 $\mathrm{mg} / \mathrm{kg}$, IP) followed by isoproterenol $(25 \mu \mathrm{g} / \mathrm{kg}$, SC) $15 \mathrm{~min}$ later. Water intake was measured as described for Experiment 1 , except the third hr measurement was omitted.

The second part of the experiment was identical to the first, except that serotonin $(2 \mathrm{mg} / \mathrm{kg}, \mathrm{SC})$ was used instead of isoproterenol as the dipsogen.

\section{Dirgs}

The 5-hydroxytryptamine creatinine sulfate complex (serotonin) was purchased from Sigma Chemical Co., St. Louis, MO. The DL-propranolol hydrochloride (Inderal ${ }^{[\hat{~}}$ ) was purchased from Ayerst Laboratories, Inc., New York, NY. The captopril (SQ 14,225) was kindly provided by Dr. $Z$. Horovitz, and the cinanserin (SQ 10,643) by Dr. S. J. Lucania of Squibb Research Institute, Princeton, NJ. The baloperidol (Haldol ${ }^{\text {B }}$ ) was obtained from NcNeil Laboratories, Ft. Washington, PA. The clonidine was a gift from Dr. P. B. Steward of Boehringer Ingelheim, LTD., Ridgefield, CT. The DL-isoproterenol hydrochlordie (Isuprel ${ }^{(1)}$ ) was purchased from Breon Laboratories, Inc., New York, NY. The methysergide maleate was a gift from Dr. C. E. Eden of Sandoz Pharmaceuticals, East Hanover, NJ.

\section{Analysis of Data}

All data are shown as the mean and standard error. The

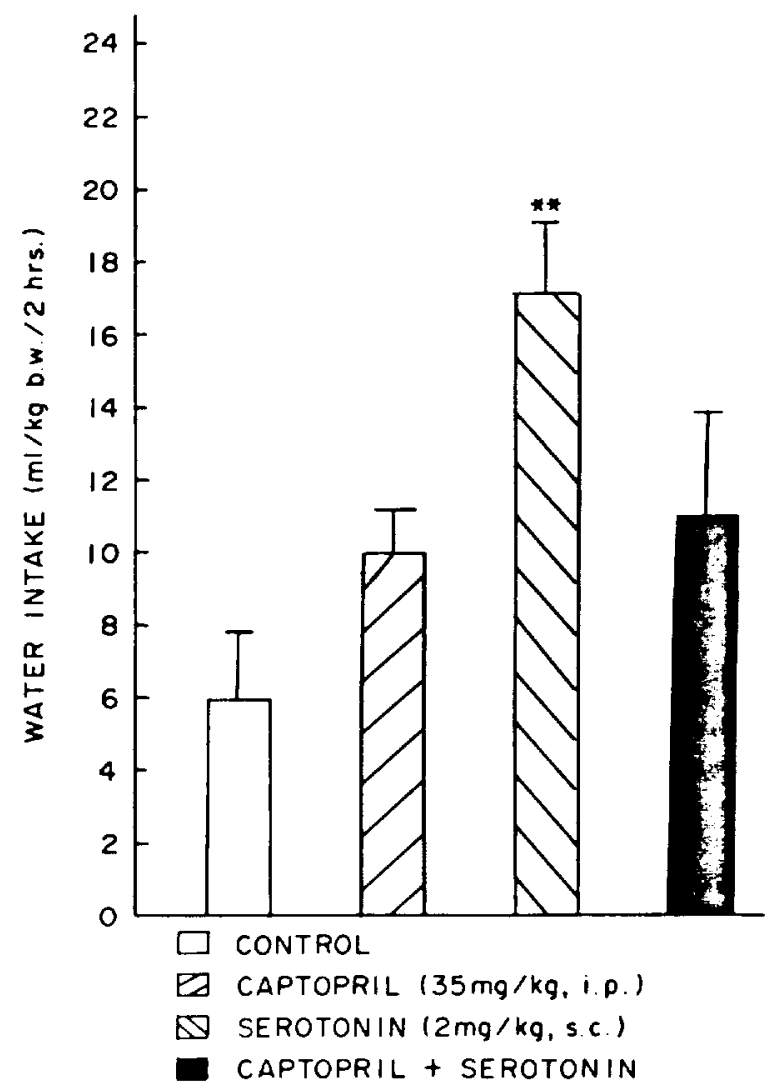

FIG. 2. Effect of pretreatment for $15 \mathrm{~min}$ with captopril $(35 \mathrm{mg} / \mathrm{kg}$, IP) on the dipsogenic response to serotonin $(2 \mathrm{mg} / \mathrm{kg}, \mathrm{SC})$. Cumulative water intake during the first $2 \mathrm{hr}$ after administration of the dipsogen is shown. Significant difference from control is denoted: ${ }^{* *} p<0.01$.

data from each experiment were analyzed statistically by means of an analysis of variance for a factorially designed experiment [5]. Differences between group means were analyzed statistically by means of a two-tailed $t$-test using the pooled variance from the analysis of variance [5]. A probability of less than 0.05 was considered significant.

RESULTS

\section{Experiment I}

Administration of serotonin was associated with a significant $(p<0.01)$ increase in water intake within $2 \mathrm{hr}$ (Fig. 1), as described previously [18]. The dipsogenic response to serotonin was inhibited by prior administration of haloperidol (Fig. 1). Similar results were obtained at 1 and $3 \mathrm{hr}$ after administration of serotonin. Haloperidol, alone, had no effect on water intake at either 1,2 or $3 \mathrm{hr}$ after administration. Using a 2-way analysis of variance, a significant $(p<0.01)$ interaction between haloperidol and serotonin on water intake was observed at all 3 time periods.

\section{Experiment 2}

Administration of captopril prevented the $2 \mathrm{hr}$ serotonininduced water intake (Fig. 2) but, when administered alone, had no effect on water intake at all times measured. Twoway analysis of variance indicated a significant $(p<0.05)$ interaction between captopril and serotonin on dipsogenesis. 


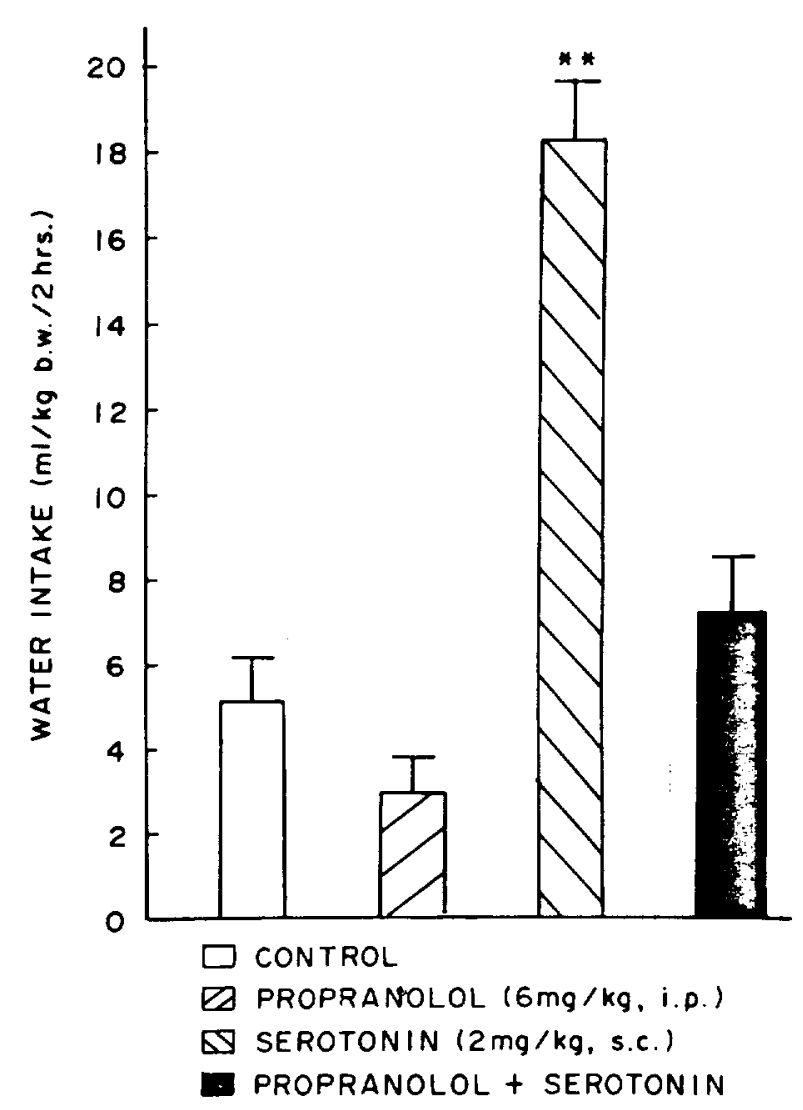

FIG. 3. Effect of pretreatment for $30 \mathrm{~min}$ with propranolol $(6 \mathrm{mg} / \mathrm{kg}$, IP) on the dipsogenic response to serotonin $(2 \mathrm{mg} / \mathrm{kg}, \mathrm{SC})$. Cumulative water intake during the first $2 \mathrm{hr}$ after administration of the dipsogen is shown. Significant difference from control is denoted: ${ }^{* *} p<0.01$.

Similar results were obtained at 1 and $3 \mathrm{hr}$ after administration of serotonin.

\section{Experiment 3}

Propranolol inhibited the $2 \mathrm{hr}$ serotonin-induced dipsogenic response (Fig. 3) but, when administered alone, had no effect on water intake at all times measured. Twoway analysis of variance revealed a significant $(p<0.01)$ interaction between propranolol and serotonin on water intake in rats. Similar results were obtained 1 and $3 \mathrm{hr}$ after administration of serotonin.

\section{Experiment 4}

Clonidine attenuated significantly $(p<0.01)$, but did not abolish completely, the $2 \mathrm{hr}$ serotonin-induced drinking response (Fig. 4). When administered alone, clonidine had no effect on water intake (Fig. 4). Similar results were obtained at 1 and $3 \mathrm{hr}$ after administration of serotonin. Two-way analysis of variance revealed a significant interaction between clonidine and serotonin on water intake after 1 $(p<0.01), 2(p<0.01)$, and $3(p<0.05) \mathrm{hr}$.

\section{Experiment 5}

Submaximal concentrations of the dipsogenic agents, serotonin [16] and isoproterenol [18], were used in this experiment in order to test whether water intake of rats ad-

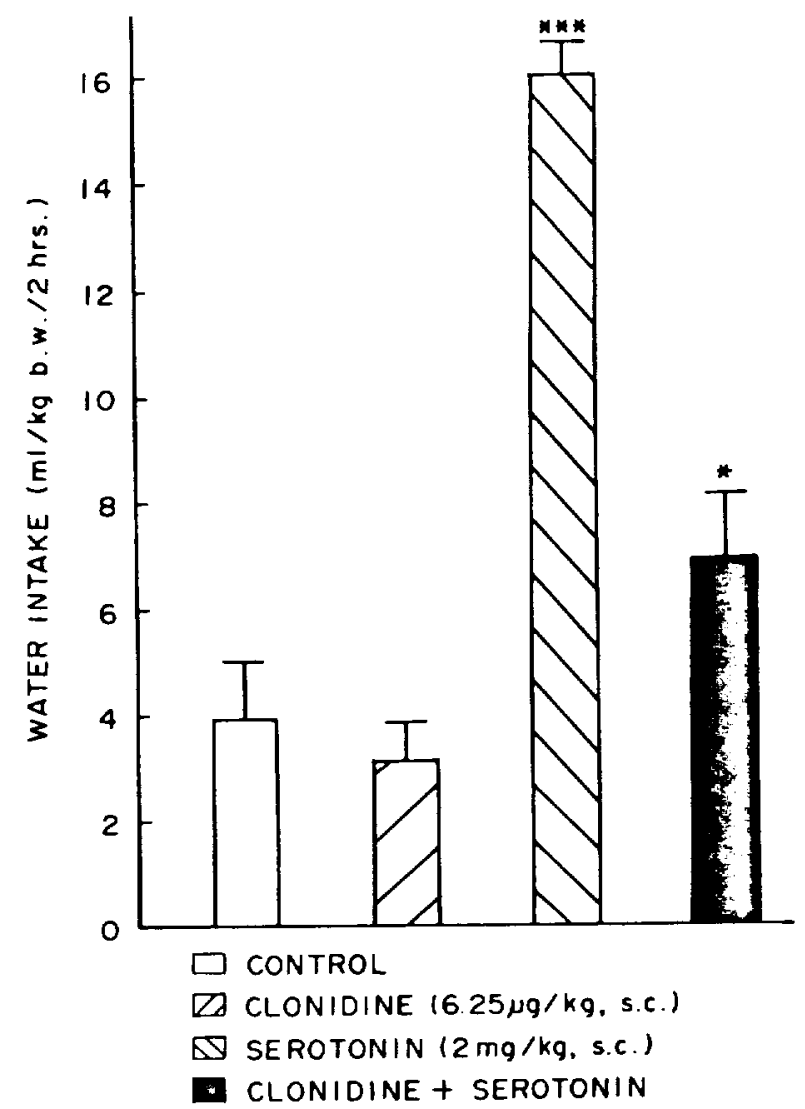

FIG. 4. Effect of pretreatment for $15 \mathrm{~min}$ with clonidine $(6.25 \mu \mathrm{g} / \mathrm{kg}$, $\mathrm{SC})$ on the dipsogenic response to serotonin $(2 \mathrm{mg} / \mathrm{kg}, \mathrm{SC})$. Cumulative water intake during the first $2 \mathrm{hr}$ after administration of the dipsogen is shown. Significant differences from control are denoted: ${ }^{*} p<0.05,{ }^{* * *} p<0.001$.

ministered both dipsogens would be either additive or interactive. Both the groups of rats receiving serotonin and those receiving isoproterenol showed significant $(p<0.01)$ increases in water intake after 2 hr (Fig. 5). Rats receiving both dipsogens showed no interaction between the two compounds on water intake, but rather a dipsogenic response approximately equal to the sum of the 2 individual responses [(serotonin-treated minus control) plus isoproterenoltreated]. Similar responses were obtained $1 \mathrm{hr}$ after administration of the dipsogenic agents.

\section{Experiment 6}

Methysergide had no effect either on basal water intake or on the $2 \mathrm{hr}$ dipsogenic response to isoproterenol (Fig. 6). Similar results were obtained $1 \mathrm{hr}$ after administration of isoproterenol. Thus, there was no interaction between methysergide and isoproterenol on water intake in rats at both times measured.

\section{Experiment 7}

Cinanserin ( $25 \mathrm{mg} / \mathrm{kg}, \mathrm{IP})$ had no effect either on basal or on isoproterenol-stimulated water intake (Table 1).

Cinanserin also had no significant effect on either 1 or $2 \mathrm{hr}$ water intakes after serotonin, although there is a hint of a reduction after $2 \mathrm{hr}$ (Table 1). In a follow-up experiment, the data from which are not reported, we found that a higher 


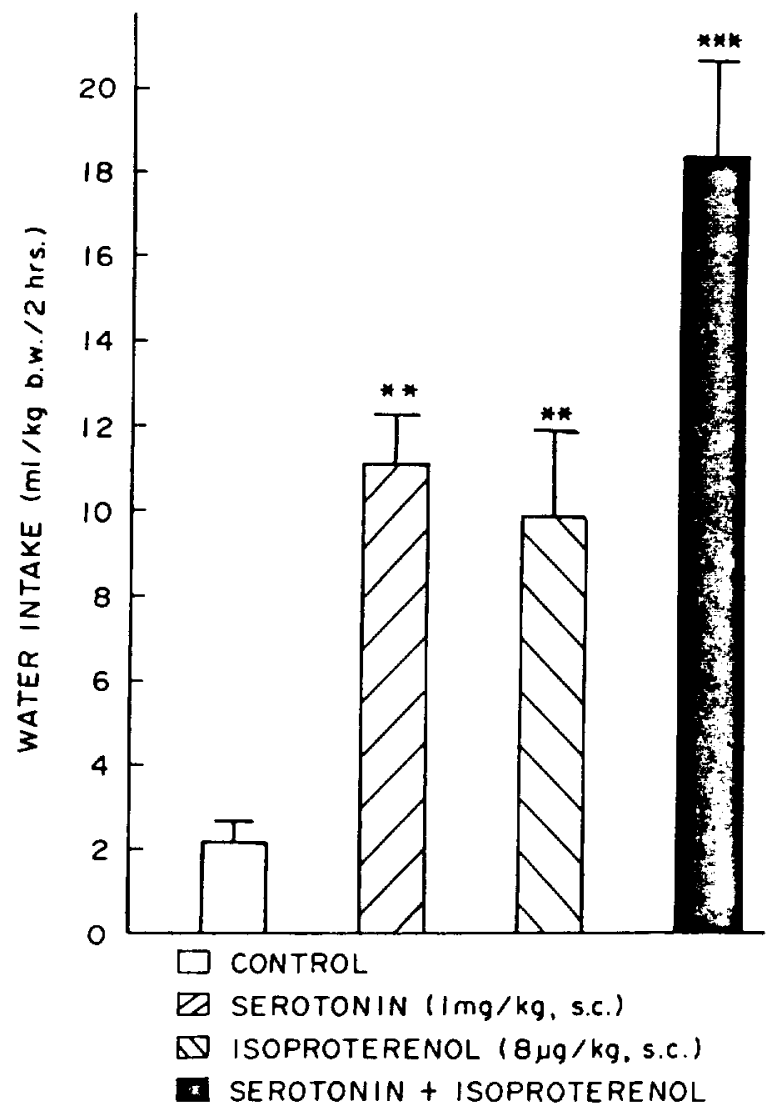

FIG. 5. Interaction between serotonin (1 mg/kg. SC) and isoproterenol $(8 \mu \mathrm{g} / \mathrm{kg}, \mathrm{SC})$ on water intake. Cumulative water intake during the first $2 \mathrm{hr}$ after administration of the dipsogens is shown. Significant differences from control are denoted: ${ }^{* *} p<0.01$. ${ }^{* * *} p<0.001$.

dose of cinanserin ( $75 \mathrm{mg} / \mathrm{kg}$, IP) produced apparent motor seizures which were not overcome by subsequent administration of serotonin $(2 \mathrm{mg} / \mathrm{kg}, \mathrm{SC})$ or $5 \mathrm{HTP}(25 \mathrm{mg} / \mathrm{kg}, \mathrm{SC})$. In this case the observed reduction of water intake was obviously a nonspecific effect of cinanserin.

\section{DISCUSSION}

L-5-Hydroxytryptophan, the immediate precursor of serotonin [20], is a potent dipsogenic agent in rats $[12,29]$ only after peripheral conversion to serotonin $[18\}$. The mechanism by which 5-HTP induces drinking in ritts $[3,29]$ is believed to be by way of the renin-angioten $\sin s y \operatorname{stcm} \mid 9,11$, 23]. Therefore, the objective of the present study was to assess the dependence of the dipsogenic response to serotonin on the renin-angiotensin system.

The dipsogenic response to serotonin was inhibited by the dopaminergic antagonist, haloperidol (Fig. 1), as was the response to 5-HTP tested in an earlier study [29]. Although haloperidol, at high concentrations, inhibits slightly central noradrenergic receptors, it is a more potent inhibitor of central dopaminergic receptors [2]. Thus, serotonin-induced dipsogenesis, like angiotensin II-induced dipsogenesis $|9,10|$, appears to be mediated through central dopaminergic neurons. Drinking induced by central administration of carbachol, a cholinergic agonist, is unaffected by central administration of haloperidol $[9,10]$. Therefore, the inhibition of

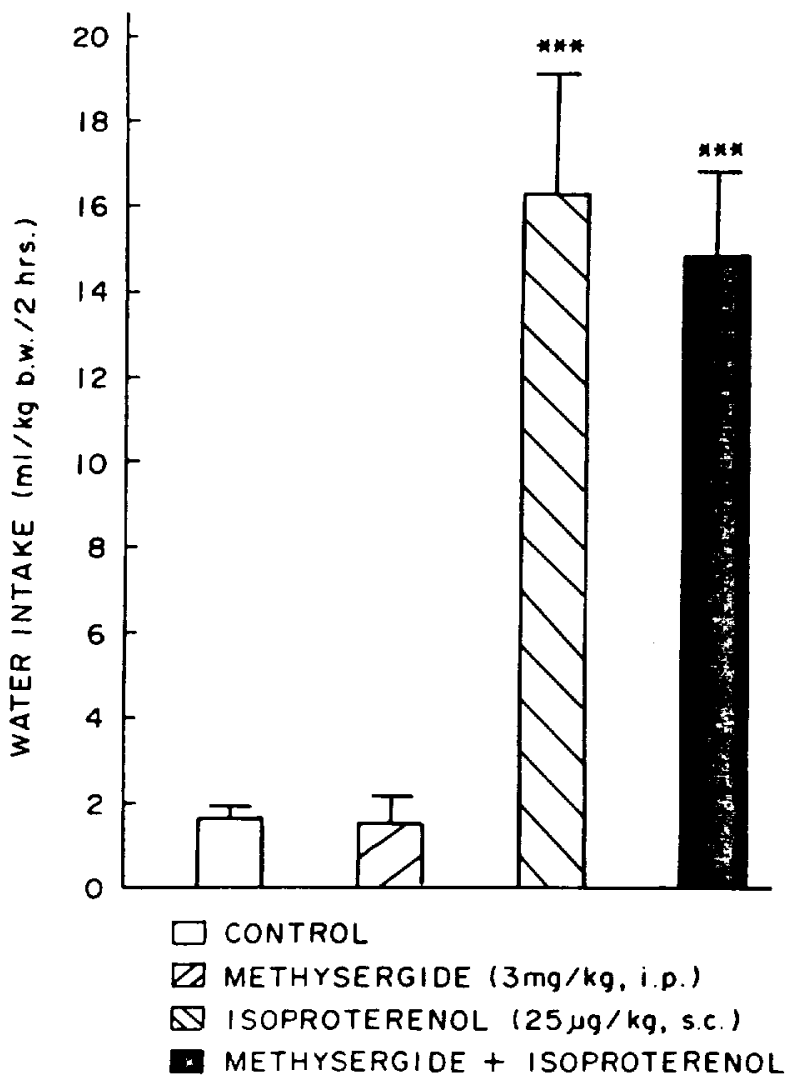

FIG. 6. Effect of pretreatment for $15 \mathrm{~min}$ with methysergide (3 $\mathrm{mg} / \mathrm{kg}$, IP) on the dipsogenic response to isoproterenol $(25 \mu \mathrm{g} / \mathrm{kg}$, SC). Cumulative water intake during the first $2 \mathrm{hr}$ after administration of the dipsogen is shown. Significant differences from control are denoted: ${ }^{* * *} p<0.001$.

both angiotensin II- and serotonin-induced dipsogenesis by haloperidol suggests that both compounds initiate drinking in the rat via the same pathway.

Captopril, an angiotensin converting enzyme inhibitor, blocked the serotonin-induced water intake (Fig. 2). Similarly, drinking in response to both 5-HTP [29] and isoproterenol [17], but not to angiotensin II [17], is inhibited by captopril. In addition, propranolol, a $\beta$-adrenergic antagonist which inhibits both isoproterenol- $[4,31]$ and 5-HTP- $[21,29]$ induced drinking and increases in plasma renin activity, hlocked serotonin-induced water intake (Fig. 3). Clonidine, an $\alpha_{2}$-adrenoceptor agonist which suppresses renin release from the kidney in rats [25], also attenuated the dipsogenic response to serotonin (Fig. 4). Although there is some controversy as to whether clonidine depresses renin release via a central [28], as opposed to a peripheral $[25,32]$ action, the fact remains that it inhibits both renin release and serotonininduced drinking in rats. In addition, clonidine has been reporled to allenuate angiotensin II-induced drinking [15]. Hence, clonidine may have antidipsogenic actions in addition 10 inhihition of renin release.

Administration of serotonin to rats is followed by a transient rise in plasma renin activity $[3,21]$. Chronic treatment of rats with desoxycorticosterone and isotonic saline as the sole drinking fuid is associated with both decreased levels of plasma renin activity [26] and attenuated dipsogenic responses to isoproterenol [14], 5-HTP and serotonin (personal 
TABLE 1

EFFECT OF CINANSERIN ON WATER INTAKE INDUCED BY ADMINISTRATION OF ISOPROTERENOL AND SEROTONIN

\begin{tabular}{|c|c|c|}
\hline \multirow[b]{2}{*}{ Treatment } & \multicolumn{2}{|c|}{$\begin{array}{l}\text { Cumulative Water Intake } \\
\text { (ml/kg b.w.) during: }\end{array}$} \\
\hline & $1 \mathrm{hr}$ & $2 \mathrm{hr}$ \\
\hline \multicolumn{3}{|l|}{ Study 1} \\
\hline Control & $1.5 \pm 0.5^{*}$ & $2.9 \pm 0.6$ \\
\hline $\begin{array}{l}\text { Cinanserin } \\
(25 \mathrm{mg} / \mathrm{kg}, \text { IP })\end{array}$ & $1.1 \pm 0.2$ & $2.6 \pm 0.9$ \\
\hline $\begin{array}{l}\text { Isoproterenol } \\
(25 \mu \mathrm{g} / \mathrm{kg}, \mathrm{SC})\end{array}$ & $12.2 \pm 0.9$ & $15.1 \pm 2.2$ \\
\hline Cinanserin + Isoproterenol & $14.6 \pm 2.8$ & $17.7 \pm 1.6$ \\
\hline \multicolumn{3}{|l|}{ Two-Way Analysis of Variance: } \\
\hline Cinanserin & NS & NS \\
\hline Isoproterenol & $<0.01$ & $<0.01$ \\
\hline Interaction & NS & NS \\
\hline \multicolumn{3}{|l|}{ Study 2} \\
\hline Control & $3.6 \pm 0.7$ & $4.2 \pm 0.7$ \\
\hline $\begin{array}{l}\text { Cinanserin } \\
(25 \mathrm{mg} / \mathrm{kg}, \text { IP })\end{array}$ & $4.2 \pm 1.6$ & $6.2 \pm 3.0$ \\
\hline $\begin{array}{l}\text { Serotonin } \\
(2 \mathrm{mg} / \mathrm{kg}, \mathrm{SC})\end{array}$ & $9.5 \pm 1.2$ & $18.6 \pm 1.1$ \\
\hline Cinanserin + Serotonin & $10.9 \pm 1.7$ & $14.7 \pm 1.9$ \\
\hline \multicolumn{3}{|l|}{ Two-Way Analysis of Variance: } \\
\hline Cinanserin & NS & NS \\
\hline Serotonin & $<0.01$ & $<0.01$ \\
\hline Interaction & NS & NS \\
\hline
\end{tabular}

*One standard error of the mean.

communication, D. Fater) while angiotensin II-induced drinking is enhanced [14]. Therefore, the preponderance of the data presented here indicates that serotonin, like 5-HTP [29] and isoproterenol [22], probably induces drinking in rats via release of renin from the kindeys and subsequent formation of the dipsogen, angiotensin II [23].

The mechanism by which serotonin induces release of renin from the kidneys is not known. There was no interaction between serotonin and isoproterenol on the dipsogenic response when rats received both compounds at submaximal doses suggesting that arousal of drinking occurs by a similar mechanism for both compounds (Fig. 5). In fact, the volumes of water ingested by rats administered the 2 compounds was approximately equal to the sum of the dipsogenic responses to the 2 compounds when administered separately. Furthermore, the dipsogenic response to isoproterenol was unaffected by pretreatment with either methysergide (Fig. 6) or cinanserin (Table 1), both of which have been reported to block the central excitatory effects of serotonin, with methysergide being 10 times as potent on a mg basis [24]. We have previously reported that methysergide blocks serotonin-induced drinking in rats [18], suggesting that sertonin acts as a point prior to activation of the renal $\beta$-adrenoceptors and the release of renin. We do not fully understand the present failure to block serotonin-induced drinking with cinanserin. It is possible that a block would have been obtained at a dose somewhere between 25 and 75 $\mathrm{mg} / \mathrm{kg}$ but the interpretation of such a result would be confounded by possible motor effects of the drug. Alternately, serotonin may act at a peripheral receptor that is not anatgonized by cinanserin.

Previous studies from this laboratory $[3,18]$ showed that serotonin acts peripherally to induce both dipsogenesis and an increase in plasma renin activity in the rat. These findings are different from those for the dog $[16,33]$ where serotonin acts centrally to increase both drinking and plasma renin activity. Van de Kar et al. [30] have suggested that the rat may be similar to the dog in this respect in that parallel decreases in both hypothalamic serotonin content and plasma renin activity occurred following central administration of several serotonin-depleting agents to rats. However, adrenal serotonin content was also reduced in their rats and could have infuenced plasma renin activity.

The present study does not elucidate the peripheral site at which serotonin acts to induce renin release. Although administration of serotonin reduces both systemic blood pressure and body temperature which could contribute to the release of renin, Barney et al. [3] found that neither action is responsible for the increase in renin release and subsequent dipsogenesis induced by the precursor of serotonin, 5 -hdyroxytryptophan. Serotonin is believed to stimulate release of catecholamines from the adrenal medulla $[6,27]$. Therefore, an increase in circulating catecholamines may result in enhanced activation of the renal $\beta$-adrenoceptors and thus an increased release of renin.

Administration of serotonin is also associated with profound renal vasoconstriction [1] which results in decreased renal blood flow $[1,7]$ even at concentrations which have no effect on systemic blood pressure [7]. A reduction in renal perfusion pressure is a potent stimulus for renin release from the juxtaglomerular cells. Thus, the possibility that serotonin may act on renal adrenergic nerve endings to release catecholamines which, in turn, stimulate the renal $\boldsymbol{\beta}$-adrenoceptors should also be considered.

Data from the present study confirm the hypothesis that serotonin induces dipsogenesis in the rat via activation of the renin-angiotensin system. However, serotonin appears to act at some step prior to the activation of the $\beta$-adrenoceptors in the kidneys. Additional studies will be required to determine the site or sites at which serotonin acts to induce the release of renin in the rat.

\section{ACKNOWLEDGEMENTS}

The authors wish to thank Mr. Juan Posada and Mr. Thomas Connor for technical assistance and Mrs. Charlotte Edelstein for the graphic illustrations.

\section{REFERENCES}

1. Adler, S. Serotonin and the kidney. In: Serotonin in Health and Disease. Vol. IV: Clinical Correlates, edited by W. B. Essman. New York: Spectrum Publications, 1977, pp. 99-137.
2. Anden, N. E., S. G. Butcher, H. Corrodi, K. Fuxe and U. Ungerstedt. Receptor activity and turnover of dopamine and noradrenaline after neuroleptics. Eur J Pharmacol 11: 303-314, 1970. 
3. Barney, C. C., R. M. Threatte, D. C. Kikta and M. J. Fregly. Effects of serotonin and /-5-hydroxytryptophan on plasma renin activity in rats. Pharmacol Biochem Behav 14: 895-900, 1981.

4. Chiaraviglio, E. Drinking behaviour in rats treated with isoprenaline, angiotensin II or angiotensin antagonists. I Physiol 296: 193-202, 1979.

5. Daniel, W. W. Biostatistics: A Foundation for Analysis in the Health Sciences. New York: John Wiley, 1974, pp. 205-266.

6. Douglas, W. W., T. Kanno and S. R. Sampson. Effects of acetylcholine and other medullary secretagogues and antagonists on the membrane potential of adrenal chromaffin cells: an analysis employing techniques of tissue culture. $J$ Physiol (Lond) 188: 107-120, 1967.

7. Erspamer, V. and A. Ottolenghi. Pharmacological studies on enteramine VIII. Action of enteramine on the diuresis and the renal circulation of the rat. Arch Int Pharmacodyn 93: 177-201, 1953.

8. Findlay, A. L. R., J. T. Fitzsimons and J. Kucharczyk. Dependence of sponataneous and angiotensin-induced drinking in the rat upon the oestrus cycle and ovarian hormones. $J$ Endocrinol 82: 215-225, 1979.

9. Fitzsimons, J. T. Thirst. Physiol Rev 52: 468-561, 1972.

10. Fitzsimons, J. T. and P. E. Setler. The relative importance of central nervous catecholaminergic and cholinergic mechanisms in drinking in response to angiotensin and other thirst stimuli. $J$ Physiol (Lond) 250: 613-631, 1975.

11. Fitzsimons, J. T. and B. J. Simons. The effect on drinking in the rat of intravenous infusion of angiotensin, given alone or in combination with other stimuli of thirst. J Physiol (Lond) 203: 45-57, 1969.

12. Fregly, M. J., T. M. Connor, D. C. Kikta and R. M. Threatte. Dipsogenic effect of $l$-5-hydroxytryptophan in rats. Brain Res Bull 5: 719-724, 1980.

13. Fregly, M. J., D. C. Fater and J. E. Greenleaf. Effect of the angiotensin I converting enzyme inhibitor, MK-421, on experimentally induced drinking. Appetite : 309-319, 1982.

14. Fregly, M. J., M. J. Katovich and C. C. Barney. Effect of chronic treatment with desoxycorticosterone on the dipsogenic response of rats to isoproterenol and angiotensin. Pharmacology 19: 165-172, 1979.

15. Fregly, M. J., D. L. Kelleher and J. E. Greenleaf. Antidipsogenic effect of clonidine on angiotensin II-, hypertonic saline-, pilocarpine- and dehydration-induced water intakes. Brain Res Bull 7: 661-664. 1981.

16. Ganong, W. F., C. D. Rudolph and H. Zimmermann. Neuroendocrine components in the regulation of blood pressure and renin secretion. Hypertension 1: 207-218, 1979.

17. Katovich, M. J., C. C. Barney, M. J. Fregly and R. E. McCaa. Effect of an angiotensin converting enzyme inhibitor (SQ $14,225)$ on $\beta$-adrenergic and angiotensin-induced thirst. Eur $J$ Pharmacol 56: 123-130, 1979.
18. Kikta, D. C., R. M. Threatte, C. C. Barney, M. J. Fregly and J. E. Greenleaf. Peripheral conversion of 1-5-hydroxytryptophan to serotonin induces drinking in rats. Pharmacol Biochem Behav 14: 889-893, 1981.

19. Lazarow, A. Methods for quantitative measurement of water intake. Methods Med Res 6: 225-229, 1954.

20. Lovenberg, W., H. Weissbach and S. Udenfriend. Aromatic l-amino acid decarboxylase. J Biol Chem 237: 89-92, 1962.

21. Meyer, D. K., M. Abele and G. Herting. Influence of serotonin on water intake and the renin-angiotensin system in the rat. Arch Int Pharmacodyn 212: 130-140, 1974.

22. Meyer, D. K. and G. Herting. Regulation of water intake. In: Handbook of Experimental Pharmacology. Vol 54: Adrenergic Activators and Inhibitors, Part I, edited by L. Szekers. Heidelberg: Springer-Verlag, 1980, pp. 579-594.

23. Oparil, S. and E. Haber. The renin-angiotensin system. $N$ Engl J Med 291: 389-401, 1974.

24. Peroutka, S. J. and S. H. Snyder. Recognition of multiple serotonin receptor binding sites. In: Serotonin In Biological Psychiatry, edited by B. T. Ho, J. C. Schoolar and E. Usdin. New York: Raven Press, 1982, pp. 155-172.

25. Pettinger, W. A.. T. K. Keeton, W. B. Campbell and D. C. Harper. Evidence for a renal $\alpha$-adrenergic receptor inhibiting renin release. Circ Res 38: 338-346, 1976.

26. Pettinger, W. A.. M. Marchelle and L. Augusto. Renin suppression by $\mathrm{DOC}$ and $\mathrm{NaCl}$ in the rat. Am J Physiol 221: 10711074, 1971.

27. Reid, G. and M. Rand. Physiological actions of the partially purified serum vasoconstrictor (serotonin). Aust J Exp Biol 29: $401-415,1951$.

28. Reid, I. A., D. M. MacDonald, B. Pachnis and W. F. Ganong. Studies concerning the mechanism of suppression of renin secretion by clonidine. J Pharmacol Exp Ther 192: 713-721, 1975.

29. Threatte, R. M., M. J. Fregly, T. M. Connor and D. C. Kikta. L-5-Hydroxytryptophan-induced drinking in rats: Possible mechanisms for induction. Pharmacol Biochem Behav 14: 385$391,1981$.

30. Van de Kar, L. D., C. W. Wilkinson and W. F. Ganong. Pharmacological evidence for a role of brain serotonin in the maintenance of plasma renin activity in unanesthetized rats. $J$ Pharmacol Exp Ther 219: 85-90, 1981.

31. Weinberger, M. H., W. Aoi and D. P. Henry. Direct effect of beta-adrenergic stimulation on renin release by rat kidney slice in vitro. Circ Res 37: 318-324, 1975.

32. Woodcock, E. A. and C. I. Johnston. $\alpha$-Adrenergic receptors modulate $\beta$-receptor affinity in rat kidney membranes. Nature 286: $159-160,1980$.

33. Zimmermannn, H. and W, F Ganong. Pharmacological evidence that stimulation of central serotonergic pathways increases renin secretion. Neuroendocrinology 30: 101-109, 1980. 